\title{
A Valuable Research
}

Gayane Gasparyan

Yerevan Brusov State University of

Languages and Social Sciences

\section{Raphael Lemkin's Draft Convention on Genocide and the 1948 UN Convention: A Comparative Discourse Study \\ S. Gasparyan, Sh. Paronyan, A. Chubaryan, G. Muradyan \\ Yerevan: YSU Press, 2016, 176 pp.}

The contemporary approach towards historical events combines different types of comprehensive research based specifically on two chief directions historical discourse and political discourse analysis. They are interrelated and interdependent as both have a certain portion of contribution to the formation of the so-called "new knowledge" in new circumstances and new readings of historical past. Any historical situation has its definite reasonable or nonreasonable motive. It is politicized and politically multidimensional as its interpretation depends absolutely on how it is viewed by different statesmen, leaders, politicians, historians or researchers of any field concerned.

Due to recent political perspectives and recent interpretations of the past events historical past acquires new properties especially in the modern world marked with a new cycle of political conflicts. This is why political discourse analysis is actually becoming an essential part of multifunctional and comprehensive research to solve the past and newly emerging problems, as to avoid miscommunication it is necessary to accurately decode disputes and misunderstandings.

The phenomenon of genocide is regarded today as a variety of political discourse explored by historians, political analysts, lawyers, journalists, linguists. The research under review is a thorough survey of the genocide phenomenon as a crime against humanity, a matter of debates and conflicts at different levels. As a matter of fact the language at all these levels becomes a 
tool through which comments, opinions, and discords come afore. That is why cognitive linguistic research in this field is highly prioritized since it facilitates the understanding of mechanisms of world perception, in this particular case the mechanisms related to the phenomenon of genocide.

Today the promotion of research on the linguistic aspects of historical and legal studies, as well as legal documents on genocides should be considered one of the most important measures in the area of Genocide Studies. The Armenian Genocide has received wide resonance all over the globe, hence, there is voluminous Englishlanguage literature on this matter. But it does not mean, that all the works are based on objective research that realistically picture the events. Part of that research is implicitly or explicitly aimed at misleading people's consciousness. The Armenians still have a lot to do in ensuring a multifaceted coverage of the most painful episode of the Armenian history, and thoroughly presenting the details of the monstrous act of genocide at the international level. Therefore, our current task is not only to present to the English language reader profound scholarly materials on the objective facts of the Armenian Genocide, but also react to historical and legal research published in the past, as well as works depicting the distorted historical reality, reveal the fraud and hypocrisy embodied in them. Here the role of Armenian specialists of English linguistics is undeniably great because they master the nuances and subtleties of the English language and speech structures, and can reveal the arsenal of linguistic strategies used by authors in their texts to influence the reader, generate opinions, communicate additional information by means of linguistic analyses.

Manifestly in Armenia we have already had the experience of conducting such research. In 2014 Professor Seda Gasparyan, Head of English Philology Department at Yerevan State University, Corresponding Member of RA National Academy of Sciences, an author of many articles on Genocide Studies and Armenian Studies, authored and published a unique research work - "The Armenian Genocide: A Linguocognitive Perspective", which undertakes a cognitive linguistic study of historiographic works on Genocide in English by a number of foreign scholars. This piece of research elicits the possibilities of 
linguistic, particularly, cognitive linguistic studies in revealing the fargoing communication goals of the authors (regardless of its essence - be it historiographic, legal, fiction or other) and the linguistic means they deploy to influence the reader.

The research under review is the outcome of dedication to thorough and accurate scientific work by S. Gasparyan and her team (Sh. Paronyan, A. Chubaryan, G. Muradyan). It is concerned with two legal documents related to the area of Genocide Studies, namely the comparative examination of the texts of R. Lemkin's Draft Convention on the Crime of Genocide presented in 1947 and the 1948 UN "Convention on the Prevention and Punishment of the Crime of Genocide." This study is unique in its kind because it examines two versions of the same legal document - the draft of the legal document condemning the Genocide to prevent another such occurrence, developed by the initiative and immediate participation of the genocide scholar, lawyer and public figure R. Lemkin, and the legally binding Convention adopted by the UN in 1948. And once again necessity emerges to address and to re-value the Convention within the more general context of the Centennial of the Armenian Genocide and the Turkish policy of denial.

The Genocide Convention is the first legal document passed by the UN in relation to human rights, that aims to protect national, racial, religious, ethnic and other minorities from the threats they may face struggling against racism and discrimination. As the authors mention, numerous studies have been devoted to the analysis of the two documents taken separately, as well as to their comparative analysis, however, they have been done in the sphere of legal studies, referring to the flaws, shortcomings and legal deficiencies and inadequacies. The research is beneficially different from the rest since it embraces a wide linguistic horizon. The authors describe the general profile of legal English, and the linguostylistic, pragmatic, semantic, grammatical features of the language of the documents under study. The present examination carried out on the basis of cognitive linguistics allows to elucidate the so-called "hidden intent," called presupposition in linguistics, of the skillful lawyers authoring 
this highly significant legal document to reveal the discursive tactics of fortifying or weakening the impact of certain provisions of this important document, to make specific provisions clearer and unambiguous, or on the contrary, to make them sound ambiguous. The authors of this research righteously mention that as an official document the text of the Convention should be devoid of any ambiguity and undesirable implicature.

The comparative analysis of the two texts shows how the communicative impact of the Convention discourse changes after Lemkin's draft is edited, some of the provisions are reformulated, a number of important ideas contracted and omitted, changing the tonality of the text, the stress on their standpoint in the condemnation of the crime against humanity. The main study of the documents has been carried out not only from different linguistic angles - stylistics, pragmatics, semantics, grammar and others, but with the examination of various linguistic elements - words, word combinations, utterances, etc. Thus, the examination of the Preamble of the Draft Convention shows that the emotive and evaluative nuances are due to the use of the vocabulary with some stylistic charge. Words and expressions with negative connotation are highlighted. They simultaneously describe the action (defies, inflicts, deprives, destroys, is against) and the consequences of genocide (inseparable loss, being intentional destruction, in violent contradiction with the spirit and aims of the United Nations, odious crime), and serve the purpose of intensifying the negative attitude of the authors towards violence also (pp. 72-73). The desirable attitude towards the crime of genocide on the part of the UN Member States is named by the following linguistic units: to oppose, prevent and repress (p. 73). The comparative analysis of the opening part of the 1948 Convention shows that the official text is more reserved in its criticism and condemnation, since the lexical units contained in it are presumably due to compromised choice, semantically they are more neutral and devoid of determination. Here is an example: the Draft contains the expression "is in violent contradiction with the spirit and aims of the United Nations" which was replaced by "contrary to the spirit and aims of the United Nations" in the Convention. The authors of the study are convinced that as a result of the 
substitution of the word contradiction for contrary semantically rather close to the former, the strong emotional negative colouring particularly intensified due to the use of the adjective violent is significantly weakened in the final text of the Convention. This also undermines the determination to manifest the necessary attitude of intolerance towards genocides (p. 75). The expression "odious crime" used in the Draft has been replaced by "odious scourge" (cause of suffering) in the Convention, weakening the spirit of intolerance against barbarism and manifestation of the monstrous nature of genocide (pp. 76-77).

From pragmatic, cognitive, semantic and grammatical perspectives an accomplished analysis has been done on the material of the definition of genocide as a criminal act, presented in Lemkin's Draft (Article I). Undertaking an analysis of the actualization of different sememes of the word "act", studying the use of that linguistic unit in the paradigmatic and syntagmatic systems and conducting contextual analysis, the authors come to the conclusion that in the Draft the word "genocide" is used in two meanings of the word "act": as a completed tragic happening in the past, and as a probable destructive happening which may occur in the future. The cognitive-pragmatic analysis reveals that Lemkin's introduction is drafted to have a perlocutive effect - condemnation of genocide. Yet, as a result of changes introduced into the language of the Convention text, the perlocutive effect is not manifest. It is also noteworthy that in the course of the comparative analysis of the documents, the authors apply contextual and co-textual analyses. Examining the text of the Convention (Article I) they refer to the historical context and draw parallels with the Armenian Genocide, specifically pointing to the parts of the text that implicitly refer to the Ottoman atrocities. Thus, analyzing a section from the Convention which touches upon the genocides of the past and the need for international cooperation for their prevention, the authors righteously conclude that genocide is a crime and remains punishable beyond any time limitations, never ceases to be punishable. Hence, they are hopeful that the contemporary successors of the Ottoman Empire will one day answer for what their ancestors have done (p. 80). 
The contextual analysis of the draft version of the document makes the socalled Armenian and Jewish footprint obvious and reveals the fact that the Convention has been written against the background of a concrete precedent and contains extralinguistic constituents and situational elements which testify to past genocidal events (pp. 87-88). By means of co-textual analysis the authors refer to the Holocaust by fascist Germany, as well as the genocidal actions and attempts of ethnic, national and religious mass cleansings of modern times (in Rwanda, Nagorno Karabakh and so on). The comparative analysis enables to reveal the inconsistencies between the provisions of the Draft and the Convention in terms of the text per se, the aim of the articles, as well as the language used. Many researchers have qualified the fact of omitting the idea of cultural destruction and the aspects related to political and social groups from the final text of the Convention as a deficiency, though R. Lemkin gave a lot of thought to them, considering these aspects as major elements of paramount importance of the concept of genocide. That has narrowed down the possibilities of qualifying destruction of cultural values as genocide, consequently, the possibilities for their prevention and punishment.

The comparative analysis brings out the concrete linguistic tactics - stylistic devices, connotative meanings, grammatical structures, illocutive and perloctive acts employed to ensure the semantic modifications in the final text of the Convention. From the perspective of linguistic analysis it is also interesting to note the innovative approach to the comparative analysis of the frequency of occurrence of words in the two documents, presented in the form of tables and graphs. By means of this methodology the authors have succeeded in disclosing the content and language similarities and differences between the abovementioned pieces of legal discourse. As the authors rightly mention, legal discourse is a dual phenomenon. On the one hand, it is a linguistic act, actualized by means of communication through words. On the other hand, it is also a legal act which serves the objectives of the legal domain (p. 126). Lemkin made great efforts to criminalize the acts of violence against humanity, to prevent and punish the acts taken to destroy the world civilization. When 
formulating the text of the Convention, the lexical, morphological, and syntactic changes caused a weakening of the spirit of intolerance towards genocides and undermined the determination to strictly punish those who undertake any such crime against humanity.

The research presented to the readers' attention is one of this kind. Patriotic work has been done which is of especially high significance for our reality, our history and our people, because one of the most terrifying pages of human history is unfortunately related to us - Armenians. The Armenian people that fell prey to the yataghan of barbaric Turks have lived through indescribable sufferings - forced physical extermination, psychological stress, reconceptualization of life, loss of historical and cultural heritage, surviving and proving indestructible and invincible, though going through complicated linguistic and cultural adaptation. The Armenian people, torn to pieces and dispersed all over the world, perhaps are still unable to get rid of the mental imbalance caused not only by extermination, forced deportation, and other circumstances disrupting their national identity and collective consciousness, but by the injustice, indifference, permissiveness and denial of the historical truth. This does not certainly mean that the humanity has ignored the fact of this terrible crime and has failed to address it. Genocide Studies present a serious area of international research that concerns itself with diverse topics on issues related to the intentional destruction of the Armenians, and other nations also, religious and racial groups, viewing these matters from the perspectives of history, law, political science, and sociology. Undoubtedly, a considerable share of scientific research in this area is dedicated to the Armenian Genocide, since scholars in history, legal studies, political science, psychology and sociology, who acknowledge their responsibility for the future of humanity, realize that the only way to prevent this villainous phenomenon is to voice and condemn it.

To conclude, I would like to state again and again the importance of the research for our reality and our nation and to express my profound gratitude to the team of authors for the significant and valuable work they have done. 